\title{
Quality-of-life among Syrian refugees residing outside camps in Jordan relative to Jordanians and other countries
}

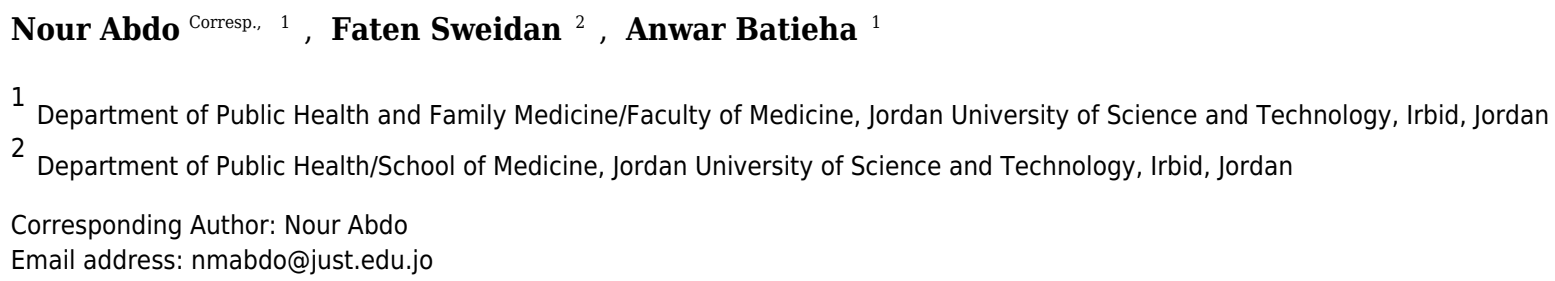

Background: Since the beginning of the Syrian humanitarian crisis, Syrians sought refuge to many safer countries. Many aspects of Syrians refugees' lives have been affected, hence affecting the overall quality of their lives. However, only one study has investigated their quality-of-life (QOL). The aim of this study is to assess the QOL of Syrian refugees residing outside camps in Jordan and compare it to the QOL of Jordanians and to other refugees and populations around the globe. Methods: Data were obtained from Syrian refugees residing outside camps in Jordan, and from two Jordanian groups; low socioeconomic status (LSES) Jordanians and average socioeconomic status (ASES) Jordanians in 2017. Six hundred and sixty one Syrians, 208 LSES Jordanians and 714 ASES Jordanians, aged between 18 and 75 years were included. The World Health Organization Quality of Life instrument (WHOQOL-BREF) questionnaire was used as the QOL assessment tool. Analysis of Variance "ANOVA" and post hoc Tukey-Honest tests were used to find the differences between the means of QOL questions in the three groups (Syrians, ASES, and LSES). Stepwise multivariate linear regression was performed for each domain to determine the most associated risk factors. Results: No significant difference was found between Syrian refugees and LSES Jordanians in the physical health domain. Syrian refugees scored significantly lower than LSES Jordanians in the psychological health and social relationship domain. Syrian refugees scored significantly higher than LSES Jordanians in the environmental domain. ASES Jordanians scored significantly higher than the other two groups in all domains, with all its scores above the average. Discussion: Despite the support Jordan provides to the Syrian refugees, they still seem to suffer the psychological health, social relationships and the environmental domains, with scores below 50 on (0-100) scale. Nonetheless, no significant difference was found between Syrian refugees and LSES Jordanians in the physical health domain, furthermore they scored significantly higher than LSES. Jordanians in the environmental domain despite both scoring below 50 on (0-100) scale in this domain. Physical, psychological, and social 
domains were mainly affected by having a job, having higher income, and being married and free from diseases. 


\section{Quality-of-Life among Syrian refugees residing outside camps in Jordan relative to Jordanians and other countries

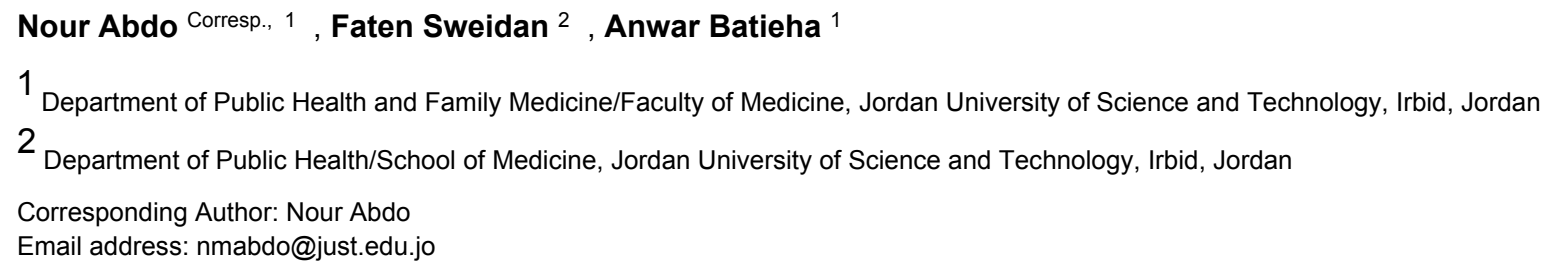

Background: Since the beginning of the Syrian humanitarian crisis, Syrians sought refuge to many safer countries. Many aspects of Syrians refugees' lives have been affected, hence affecting the overall quality of their lives. However, only one study has investigated their quality-of-life (QOL). The aim of this study is to assess the QOL of Syrian refugees residing outside camps in Jordan and compare it to the QOL of Jordanians and to other refugees and populations around the globe.

Methods: Data were obtained from Syrian refugees residing outside camps in Jordan, and from two Jordanian groups; low socioeconomic status (LSES) Jordanians and average socioeconomic status (ASES) Jordanians in 2017. Six hundred and sixty one Syrians, 208 LSES Jordanians and 714 ASES Jordanians, aged between 18 and 75 years were included. The World Health Organization Quality of Life instrument (WHOQOL-BREF) questionnaire was used as the QOL assessment tool. Analysis of Variance "ANOVA" and post hoc Tukey-Honest tests were used to find the differences between the means of QOL questions in the three groups (Syrians, ASES, and LSES). Stepwise multivariate linear regression was performed for each domain to determine the most associated risk factors.

Results: No significant difference was found between Syrian refugees and LSES Jordanians in the physical health domain. Syrian refugees scored significantly lower than LSES Jordanians in the psychological health and social 
41 relationship domain. Syrian refugees scored significantly higher than LSES

42 Jordanians in the environmental domain. ASES Jordanians scored significantly

43 higher than the other two groups in all domains, with all its scores above the 44 average.

45 Discussion: Despite the support Jordan provides to the Syrian refugees, they still seem to suffer the psychological health, social relationships and the environmental domains, with scores below 50 on (0-100) scale. Nonetheless, no significant difference was found between Syrian refugees and LSES Jordanians in the physical health domain, furthermore they scored significantly higher than LSES. Jordanians in the environmental domain despite both scoring below 50 on (0100) scale in this domain. Physical, psychological, and social domains were mainly affected by having a job, having higher income, and being married and free from diseases. 
77

78

79

80
Since the beginning of the civil war in Syria, more than five million Syrians are registered as refugees. Around three million Syrian refugees are registered in Turkey and the remaining two million are mainly $(80 \%)$ registered in Lebanon and Jordan. The rest are registered in Iraq and Egypt. Almost 19\% of the registered refugees in Jordan are residing in camps (UNHCR 2018) . Jordan has registered more than 673,000 in the UNHCR databases (UNHCR 2018). According to the UNHCR database, five camps are available for Syrian refugees in Jordan, and the main three camps are Al-Zaatari camp with 78,545, Al-Azraq camp with 40,738, and the Emirati Jordanian camp with 6,848 refugees. The remaining reside outside camps. Camps are the first stop for refugees without identification documents, they have the choice to stay and benefit from the privileges the camp has to offer, or leave to depart from the camp, and be responsible for providing food, rent, medical care and education for their families (Rami 2017).

Quality of Life (QOL) can be defined as the general well-being of individuals and societies, outlining negative and positive features of life. It observes life satisfaction, including everything from physical health, family, education, employment, wealth, religious beliefs, finance and the environment (School 2013). Forced displacement of Syrians affected their QOL, including its psychological (Weinstein et al. 2016), physical (Doocy et al. 2016), and social aspects (Sevinc et al. 2016). Syrian refugees have suffered several psychological consequences. The literature has shown that Syrian refugees are struggling with deep pain and distress due to poverty, job insecurity, and unemployment (Anagnostopoulos et al. 2016). Furthermore, many of them were diagnosed with depression, generalized stress and post-traumatic stress disorder (PTSD) (Weinstein et al. 2016). On the other hand, the physical health of Syrian refugees was also distraught. Due to hospitals destructions and chaos, as a result of the Syrian civil war, severe disruptions to health care services were observed (Ozaras et al. 2016). 
Consequently, several infectious diseases have reemerged (Ozaras et al. 2016), and an increase in the prevalence of uncontrolled non-communicable diseases was observed (Gammouh et al. 2015). The nutritional status of the refugees were also a field of study, as literature shows high prevalence of anemia among non-pregnant Syrian women and children in the camp settings (Bilukha et al. 2014).

Our study was the first to assess the QOL of Syrian refugees residing outside camps. There was only one study that focused on the QOL of Syrian refugees, and was conducted on the Syrian refugees' camp population in Kurdistan (Aziz et al. 2014). No studies were found concerning the QOL of Syrian refugees residing outside camps. This study is a great opportunity to illuminate our understanding on how Syrian refugees outside camps are coping with their new environment. Furthermore, the study provided a snapshot estimation of QOL among two Jordanian groups (middle income Jordanians and Jordanians with low-socioeconomic status). Moreover, the results of this research will help the government, as well as, the external and internal donors in proper allocation of their financial and medical assistance.

This study assessed the QOL of registered refugees, therefore, it was not representative of unregistered refugees, who were unable to get access to healthcare the way registered Syrian refugees do; similarly the studied population were urban area residents and they had no access to the free accommodation, health services, food and education privileges that camp residents have.

\section{Materials \& Methods}

\section{Sample and Sampling Procedure}

The following three groups were recruited: Syrian refugees, ASES Jordanians, and LSES 
125 Jordanians. A total sample of 1583 participants was collected as detailed below. It included

126 everyone willing to participate aged 18 years old or above. Data collection took place between

127 February and August 2017.

128

129

130

131

132

\section{Syrian Refugees}

Syrian refugees was recruited from the refugees and their companions (if any), who sought Caritas Al-Husn center for humanitarian and medical services between February and June 2017. Caritas Al-Husn center serves Syrian refugees residing outside camps as well as vulnerable Jordanians. Caritas Al-Husn center refers some of the beneficiaries to a local pharmacy, so we used the pharmacy as a data collection point when data collection became hard to accomplish at the center due to the increase in beneficiary numbers and no proper space was available for data collection anymore. Data collection was also performed at two humanitarian assistance campaigns for the Syrian refugees; they were designed to provide food, and took place at Al Hasan sports City-Irbid during the data collection period.

\section{Average socioeconomic status (ASES) Jordanians}

ASES Jordanians were defined as people with average living circumstances, and not eligible for the Social Development Department (SDD) financial assistance. This category was recruited from Al-Husn Health Care Center from February to August 2017. Everyone who attended the clinic in the specified period and willing to participate was included in the study.

\section{Low socioeconomic status (LSES) Jordanians}

LSES Jordanians were defined as people who are eligible for services and assistance from the Social Development Department (SDD). The SDD has a strict vetting system to identify their eligibility. The SDD conducts a social vulnerability study to for the applicants who are seeking financial 
151

152

153 154 155

160

161

162

163

164

165

166

167

168

169

170

171

172

173

174

175

176

assistance, and request number of documents: bank statements showing the monthly salary, loans and monthly deductions, prison services certificate, detailed medical reports explaining the reason why the family should get financial assistance from SDD, detailed medical reports for any disabled family members, divorce and custody certificates, alongside their Identification documents including the family book and the identification cards (Development 2018) recruited LSES Jordanians from SDD in Irbid. Anyone who attended the SDD from February to May 2017 and willing to participate was included in the study.

\section{Data Collection}

\section{Measures}

WHOQOL-BREF is QOL assessment tool, developed by the WHO . WHOQOL-BREF is the short version of much detailed questionnaire, WHOQOL-100 and can be used as an efficient alternative in studies aiming to assess QOL. WHOQOL-BREF is much more practical to use in the surveys than WHOQOL-100 as using 26 questions to assess the QOL is easier than using 100 questions in the original version. It's rapid, easy and gives good estimate of the overall QOL. WHOQOL-BREF assesses the quality of physical health (7 items; e.g., "To what extent do you feel that physical pain prevents you from doing what you need to do?"), psychological health (6 items; e.g., "How satisfied are you with yourself?",social QOL (3 items; e.g., "How satisfied are you with the support you get from your friends?"), and environmental QOL (8 items; e.g.,"How healthy is your physical environment?").

Answers were scored from one to five with various anchor statements (e.g., from [Very dissatisfied] to [Very satisfied] or [Very poor] to [Very good]), except for question 26 that asked about the frequency the subject experiences negative feelings, its anchor statements had different meanings; [1: Never], [2: Seldom], [3: Quite often], [4: Very often] and [5: Always].The 
177 psychometric properties of the WHOQOL-BREF's have been validated as a QOL assessment

178 tool for various cultures and socioeconomic status (Skevington et al. 2004).

179

180

181

182

\section{Data Management and Statistical Analysis}

Pilot study was performed, to insure internal consistency. The test was performed on 56 participants, above 18 years of age and willing to participate from Al-Farouq health center in Irbid area. The cronbach's alpha was above 0.7 for all domains except for the social relationships domain, and according to the WHO manual, the internal consistency test for this domain cannot be trusted because it consists of three items only, so we proceeded with the actual study. Data entry and analysis was performed using SPSS-PC software v20 and SAS v9.2 software. Data cleaning was performed to check for data entry errors; we performed range and logical checks to find out possible errors in data entry. Detected errors were corrected by returning back to the study forms, remaining errors were treated as missing if they were not possible to correct.

The assessment is discarded when more than $20 \%$ of the data is missing. In the case of a missing item, the mean of other items in the domain is substituted. When two items are missing, the domain score was not calculated according to WHOQOL-BREF instructions, except for domain 3 , where the domain 3 should only be calculated if $<=1$ items is missing. The Arabic version of the WHOQOL-BREF reliability and validity has been tested through a study done among large Arabic-speaking samples (Ohaeri \& Awadalla 2009). The item of the social relationships QOL (“How satisfied are you with your sex life?") was only answered by 4.4\% Syrians, 7.7\% LSES Jordanians and 22.2\% ASES Jordanians, due to sensitivity of the question in this cultural context, although some participants did answer it. According to the WHOQOL-BREF manual, missing items are allowed in the transformational methods for scoring of the scale. ANOVA and post-hoc TukeyHonest tests were used to find the differences between the means of QOL questions in the three groups (Syrians, ASES, LSES). Stepwise multivariate linear regression was performed for each 
202 domain to determine the most associated factors. Population was included in all regression models as

203 "population" is the variable of interest in this study. In addition to population (ASES Jordanians

204 LSES Jordanians and Syrian refugees), adjustment for the following possible confounders was made:

205 age, having a chronic disease, family size, monthly income, having a job, personal description of

206 financial situation, education, marital status, and gender.

\section{Ethical Considerations}

208 The study protocol was approved from the institutional review board (IRB) of Jordan

209 University of Science and Technology (JUST) IRB 33/107/2017. All data were kept strictly

210 confidential and used only for scientific reasons without identifying information for the

211 participants. Verbal informed consent was obtained from each participant. The study carries no

212 foreseeable harm to participants as it was based on interviewing the participants without any invasive

213 procedures. Each person was given the choice of participating or not without any pressure.

214 Results

215

216

We were able to recruit 1583 participants: 661 Syrians, 714 ASES Jordanians, and 208 LSES

Jordanians. Data collection took place in Irbid area. The participants were residents of Irbid, Jarash,

218

219

220

221

222

223

224

225

226

227

228

Ajloun, AlMafraq, Amman and Al Salt.

Eight questionnaires were discarded because they had $20 \%$ or more missing data; the remaining 1575 questionnaires were eligible for analysis: Syrians 655 (41.6\%), LSES Jordanians 208

(13.2\%), and ASES Jordanians 712 (45.2\%). General demographics of the three populations are listed in Table 1.

\section{Domain Results}

\section{Physical Health Domain:}

Table 2, Figure $1 A$ shows the means of physical health domain questions for the three populations. Syrian refugees scored average or less in all the questions and were the lowest among all 
240

groups. LSES Jordanians had the highest pain tolerance among all groups (F3) among all groups, followed by Syrian refugees then ASES Jordanians. Similarly, LSES Jordanians needed less medical treatment (F4) than the other two groups, followed by Syrian refugees and ASES Jordanians. Stepwise multivariate linear regression resulted in the following: the overall physical health was better for ASES Jordanians, followed by LSES Jordanians then by the Syrian refugees. Aging, having disease, being married and increasing family size had negative effect on the overall physical health. On the other hand, higher monthly income and having a job had positive effect on the overall physical health, Table 3. Supplemental Table shows analysis stratified for each population for each domain.

\section{Psychological Health Domain:}

Although Syrian refugees scored significantly lower than both Jordanian groups when asked about their concentration ability (F7), acceptance of bodily appearance (F11) and satisfaction of oneself (F19), they still scored around average. Syrian refugees are enjoying life (F5) more than LSES Jordanians, but they scored below average.

LSES Jordanians experienced negative feelings more than the other two groups, while Syrian refugees experienced lesser amounts of negative feelings compared to other groups, Table 2, Figure 1C. Stepwise multivariate linear regression resulted in the following: the overall psychological health was better for ASES Jordanians, followed by LSES Jordanians and Syrian refugees respectively. Aging and diseases had negative effect on the overall psychological health, on the other hand higher monthly income and having a job had positive effect on the overall physical health, Table 3. Supplemental Table.

\section{Social Relationships Domain}


255 ASES Jordanians scored significantly higher than the other two groups in all questions in this

256 domain. Syrian refugees scored significantly the lowest among all groups in the first two

257 questions and higher than LSES Jordanians in the last question, Table 2, Figure $1 B$.

258 As mentioned above, a few answered Q21: (“How satisfied are you with your sex life?”), all who

259 answered scored above the cut point in the three populations, with no significant differences

260 between them.

261 After adjustment for the following factors: population (Syrian refugees, LSES, ASES), age,

262 having a chronic diseases at the time of the study, family size, monthly income, having a job at 263 the time of the study, personal description of financial situation, education, gender, and marital 264 status, stepwise multivariate linear regression resulted in the following: the overall quality of 265 social relationships was better for ASES Jordanians, followed by LSES Jordanians then Syrian 266 refugees. Diseases had negative effect on the overall quality of social relationships. High 267 monthly income and being married had positive effect on the overall physical health, Table 3. 268 Supplemental Table.

269 Syrian refugees had significantly healthier environment, were more satisfied with their 270 living conditions (F23) and had significantly more money (F12) than LSES Jordanians 271 (F9),Table 2, Figure 1D. Stepwise multivariate linear regression resulted in the following: the 272 overall environment quality was better for ASES Jordanians, followed by LSES Jordanians and 273 Syrian refugees respectively. Higher monthly income had positive effect on the overall physical 274 health. Males were more satisfied with their environment quality, Table 3. Supplemental Table.

275

276

277

278

\section{General Look at the QOL Domains for Each Population}

Syrian refugees scored significantly higher than LSES Jordanians in the environmental domain but were still below average; on the other hand they scored lower than LSES Jordanians in the 
279 psychological health and social relationship domain. No significant difference was found

280

281

282

283

284

285

286

287

288

289

290

291

292

293

294

295

296

297

298

299

300

301

302

303

between Syrian refugees and LSES Jordanians in the physical health domain. ASES Jordanians

scored the highest among all groups in all domains, with all its scores above the average, Table 4,

Figure 2.

\section{Discussion}

Since the beginning of the Syrian humanitarian crisis, Jordanian government has been trying to provide the needed care for Syrian refugees. Over the past two decades, Jordan has hosted a lot of refugees from different countries due to the political unrest in the area. After the influx of Syrian refugees to Jordan, more than 271 million JODs were needed in public health facilities, out of the 1.5 billion JODs that have been spent on healthcare services by the end of 2016, and the demand for the healthcare services is growing ( $\mathrm{Al}$ Emam 2016). Since the beginning of the crisis, more than 673,000 Syrians has registered as refugees. However, the actual number is around 1.4 million refugees and this creates a load on healthcare services. In the time period between 2012 and 2016 , the hospitals of the ministry provided services to around 630,000 Syrian refugees, with around 59,000 hospital admissions. Healthcare centers across the country received around 11 million Syrian refugees' visits (Al Emam 2016). UNHCR is also providing primary, secondary and tertiary healthcare services free of charge for vulnerable Syrians (UNHCR). We assessed in this study the QOL in a large sample of Syrian refugees, and compared it to LSES and ASES Jordanians and refugees worldwide. No studies assessed the QOL for Syrian refugees outside camps. However, one study assessed the QOL for in-camp Syrian refugees (Aziz et al. 2014), and other studies assessed the QOL for other refugees and groups (Akinyemi et al. 2012).

\section{Physical Health}

Syrian refugees had significantly lower physical pain and need for treatment than the ASES 
Jordanians, but significantly higher than LSES Jordanians. Syrian refugees also scored more or less the same as the LSES Jordanians scores in most of the physical health domain questions. The overall physical health score for the Syrian refugees were very close to LSES Jordanians and the scores were around average, in opposite to ASES Jordanians who scored above average.

Challenges are still facing Syrian refugees in obtaining healthcare services despite the assistance Jordan is trying to provide, either because of the cost, especially after the new healthcare fees imposed in 2014, lengthy bureaucratic procedures, or the lack of the documents needed for the eligibility of healthcare access. At least $58.3 \%$ of Syrian adults with chronic conditions are not able access health services including medicines, according to the UNHCR (International 2016).

\section{Psychological Health}

The psychological scores were below average for most of the questions, and the lowest among all three groups in the overall questions, those findings are maybe due to the challenges that any refugee goes through trying to build new life in different country. In the first two years of this crisis, The Ministry of Health spent about US \$53 million on care to refugees, with only US \$5 million provided by UN agencies, that being said, proper mental health care seems challenging. Finances is just one of many challenges, lack of trained mental health practitioners, and the lack of the basic factors essential to mental health, i.e.: education for children, employment for adults, comfortable and sanitary living environment are not yet accessible to many Syrian refugees in Jordan (Al Hadid 2016).

\section{Social relationships}

Syrian refugees scored significantly less than the other two groups in the overall social relationships domain, and they were not satisfied with the support they got from their friends, maybe due to the hard economical circumstances they are facing. Syrian refugees outside camps in Jordan 
scored higher than Camp refugee residents of Oru community in West Africa (Oru-Ijebu, Southwest Nigeria (Akinyemi et al. 2012)), in all Domains, except for the social relationships domain, which can be explained by the nature of the camp as it may provide more social environment.

\section{Environment}

Syrian refugees scored significantly higher than LSES Jordanians when asked about money availability; nonetheless they all scored below average. Fifth of the registered Syrian refugees with UNHCR in Jordan receive cash assistance using iris-scanning biometric technology, to help them meet their basic needs (UNHCR). In 2016, Jordanian government has legalized work for Syrian refugees by giving work permits and encouraged the Syrian refugees to get legal work permits by easing the process. However, they were cautious, because of the application procedures and the fear that their access to emergency aid would be at risk. The proportion of Syrian urban refugees who depend on humanitarian assistance as an income source, instead of work, has dramatically increased in 2016. Only 36\% of household earnings among Syrian urban refugees comes from work, and this percent continues to decline, as only $22 \%$ of them are working, compared to $35 \%$ of vulnerable Jordanians, in 2016 (CARE 2017).

The unemployment rate was high in all groups, with being unemployed was around seven times more than being employed among the Syrian refugees, four times more among LSES Jordanians and two times more among ASES Jordanians. Employment rate in Jordan on average is 32.95 between the years 2007-2018 which can explain the unemployment rate among the Jordanian groups." (CARE 2017).

\section{Syrian Urban Refugees in Jordan and Other Refugees}

Syrian refugees residing outside camps in Jordan scored lower than refugees in the camps of Gaza (Eljedi et al. 2006) and Kurdistan (Aziz et al. 2014) in the physical, psychological and 
354 social domains, and that is may be due to the availability of free services inside the camp areas

355 provided by the UNRWA and the UNHCR which offers a secure life for refugees on many

356

357

358

359

360

361

362

363

364

365

366

367

368

369

370

371

372

373

374

375

376

377

378

379

aspects; food, health, shelter and educational security, and this is not the case outside the camps.

Shelter is the

main concern for Syrian refugees outside camps in Jordan followed by utilities and education 361 (2017).

\section{Limitations}

This study was the first to assess the QOL of Syrian refugees residing outside camps, and recruited large sample size, nonetheless it has some limitations. First, recruiting LSES Jordanians was a challenging process due to the short permission time we had been given at SDD, and this resulted in smaller sample size. Second, this study assessed the QOL of registered refugees, therefore, it was not representative of unregistered refugees, who were unable to get access to healthcare the way registered Syrian refugees do. Third, minority of the population recruited answered the following question: ("How satisfied are you with your sex life?") in the social relationships domain, due to the sensitivity of the question in our cultural context. Another challenge faced in this study is that the males were less compliant when invited to participate in this study than females, which yielded in much less representation for the male perspective.

\section{Future Recommendations and Directions}

The results of this study emphasize the need for outreach and facilitation for psychological health support among both the Syrian refugees and LSES Jordanians. Additionally, Syrian refugees and LSES Jordanians need employment options. This is especially true with the nature of the long term displacement the Syrian refugees are now withstanding. Providing job opportunities for both groups is the first step toward better psychological and environmental QOL. While all 
380 Syrian children are eligible for education, a lot of adults refugees are illiterate compared to 381 Jordanians. In fact, illiteracy is $7 \%$ among Syrian refugees which is double that in our Jordanian 382 sample. Better campaigns should target illiteracy to improve the overall QOL. Finally, there is a

402

403

404

405

406

407

408 need for better fund outreach from external donor agencies to support the services provided to LSES Jordanians and Syrian refugees.

The Syrian crises did not only affect Syrians, it distressed other minorities who resided in Syria at the time of war. We recommend targeting other refugees affected by the Syrian crisis such as the Palestinian Refugees registered originally in Syria but fled to Jordan as a result of the crises.

\section{Conclusions}

ASES Jordanians scored above the average in all domains and had the highest scores among all groups. Syrian refugees scored average or less in all domains, nonetheless, they scored significantly higher than LSES Jordanians in the environmental domain. LSES Jordanians had better psychological health and social relationships than Syrian refugees. No significant difference was found between Syrian refugees and LSES Jordanians in the physical health domain. Physical, psychological, and social domains were mainly affected by having a job, having higher income, and being married and free from diseases.

7

(1)

9

0

1

3

8


420

421

422

423

424

425

426

427

428

429

430

431

432

433

434

435

436

437

438

439

440

441

442

443

444

445

446

447

448

449

450

451

452

453

454

455

\section{References}

- UNHCR "United Nations High Commissioner for Refugees". Available at http://data.unhcr.org/syrianrefugees/regional.php\# (accessed 19th Sep 2017).

- WHO The World Health Organization Quality of Life (WHOQOL). Available at http://www.who.int/mental health/publications/whogol/en/ (accessed 10 Dec 2017).

- 2017. UNHCR "United Nations High Commissioner for Refugees". Available at http://www.unhcr.org/figures-at-a-glance.htm/22 Sep 2017).

- Akinyemi OO, Owoaje ET, Ige OK, and Popoola OA. 2012. Comparative study of mental health and quality of life in long-term refugees and host populations in Oru-ljebu, Southwest Nigeria. BMC Res Notes 5:394. 10.1186/1756-0500-5-394

- Al Emam D. 2016. The Jordan Times. Available at http://www.jordantimes.com/news/local/publichealthcare-services-syrian-refugees-costing-jordan-jd271m-annually\%E2\%80\%99 (accessed 6 Feb 2018 2018).

- Al Hadid F. 2016. Mental Health of Syrian Refugees in Jordan. Available at https://yaleglobalhealthreview.com/2016/02/20/mental-health-of-syrian-refugees-in-jordan/ (accessed 7 Feb 2018 2018).

- Anagnostopoulos DC, Giannakopoulos G, and Christodoulou NG. 2016. A Compounding Mental Health Crisis: Reflections From the Greek Experience With Syrian Refugees. Am J Psychiatry 173:10811082. 10.1176/appi.ajp.2016.16060667

- Aziz IA, Hutchinson CV, and Maltby J. 2014. Quality of life of Syrian refugees living in camps in the Kurdistan Region of Iraq. PeerJ 2:e670. 10.7717/peerj.670

- Bilukha OO, Jayasekaran D, Burton A, Faender G, King'ori J, Amiri M, Jessen D, Leidman E, Division of

Global Health Protection CfGHCDC, Centers for Disease C, and Prevention. 2014. Nutritional status of women and child refugees from Syria-Jordan, April-May 2014. MMWR Morb Mortal Wkly Rep 63:638-639.

- CARE. 2017. 7 Years Into Exile: How urban Syrian refugees, vulnerable Jordanians and other refugees in

Jordan are being impacted by the Syria crisis. Available at https://reliefweb.int/report/jordan/7years-exile-how-urban-syrian-refugees-vulnerable-jordanians-and-other-refugees (accessed 8 Feb 2018 2018). 
456

457

458

459

460

461

462

463

464

465

466

467

468

469

470

471

472

473

474

475

476

477

478

479

480

481

482

483

484

485

486

487

488

490

491

492

493

494

495

496

497

498

499

500

501

502

503

504

- Doocy S, Lyles E, Akhu-Zaheya L, Burton A, and Weiss W. 2016. Health service utilization and access to

medicines among Syrian refugee children in Jordan. Int J Health Plann Manage 31:97-112.

10.1002/hpm.2336

- Eljedi A, Mikolajczyk RT, Kraemer A, and Laaser U. 2006. Health-related quality of life in diabetic patients

and controls without diabetes in refugee camps in the Gaza strip: a cross-sectional study. BMC

Public Health 6:268. 10.1186/1471-2458-6-268

- Gammouh OS, Al-Smadi AM, Tawalbeh LI, and Khoury LS. 2015. Chronic diseases, lack of medications,

and depression among Syrian refugees in Jordan, 2013-2014. Prev Chronic Dis 12:E10.

$10.5888 /$ pcd12.140424

- International A. 2016. Reliefweb. Available at https://reliefweb.int/report/jordan/living-marginssyrian-

refugees-jordan-struggle-access-health-care (accessed 7 Feb 2018 2018).

- Ohaeri JU, and Awadalla AW. 2009. The reliability and validity of the short version of the WHO Quality of

Life Instrument in an Arab general population. Ann Saudi Med 29:98-104.

- Ozaras R, Leblebicioglu H, Sunbul M, Tabak F, Balkan, II, Yemisen M, Sencan I, and Ozturk R. 2016. The

Syrian conflict and infectious diseases. Expert Rev Anti Infect Ther 14:547-555.

10.1080/14787210.2016.1177457

- Rami LQ. 2017.

- Sevinc S, Kilic SP, Ajghif M, Ozturk MH, and Karadag E. 2016. Difficulties encountered by hospitalized

Syrian refugees and their expectations from nurses. Int Nurs Rev 63:406-414. 10.1111/inr.12259

- Skevington SM, Lotfy M, O'Connell KA, and Group W. 2004. The World Health Organization's WHOQOL-

BREF quality of life assessment: psychometric properties and results of the international field

trial. A report from the WHOQOL group. Qual Life Res 13:299-310.

10.1023/B:QURE.0000018486.91360.00

- UNHCR. Reliefweb. Available at https://reliefweb.int/report/jordan/unhcr-jordan-factsheet-june$\underline{2017}$

(accessed 7 Feb 2018 2018).

- Weinstein N, Khabbaz F, and Legate N. 2016. Enhancing need satisfaction to reduce psychological distress in Syrian refugees. J Consult Clin Psychol 84:645-650. 10.1037/ccp0000095 
505

506

507

508

509

510

511

512

513

514

515

516

517

518

519

520

521

522

523

524

525

526

527

528

529

530

531

532

533

534

535

536

537

538

539

540

541

542

543

544

545

546

547

548

549

550

551

552

553

554

555

556

557

558

559

560

561
- Development MoS. 2018. Directory of services of the Ministry of Social Development. Available at $h$ ttp://www.mosd.gov.jo/UI/Arabic/SubContent.aspx?Contentld=18 (accessed 21-11-2018 2018).

- School IB. 2013. Quality Of Life: Everyone Wants It, But What Is It? Available at https://www.forbes.com/sites/iese/2013/09/04/quality-of-life-everyone-wants-it-but-what-isit/\#1561c446635d2018).

- $\quad$ UNHCR. 2018. UNHCR "United Nations High Commissioner for Refugees". Available at https://data2.unhcr.org/en/situations/syria/location/36 (accessed 21-11-2018 2018).

PeerJ reviewing PDF | (2018:07:30064:0:1:NEW 16 Sep 2018) 


\section{Figure 1}

Quality-of-life domain question's means in Syrians refugees residing outside camps in Jordan and Jordanians

(A) The mean score for each question in the Physical-Health domain for Syrian refugees (red), LSES Jordanians (blue), ASES (green). (B) The mean score for each question in the Social domain for Syrian refugees (red), LSES Jordanians (blue), ASES (green). (C) The mean score for each question in the Psychologcial-Health domain for Syrian refugees (red), LSES

Jordanians (blue), ASES (green). (D) The means score for each question in theEnvironmentalHealth domain for Syrian refugees (red), LSES Jordanians (blue), ASES (green). 
A

Physical Domain

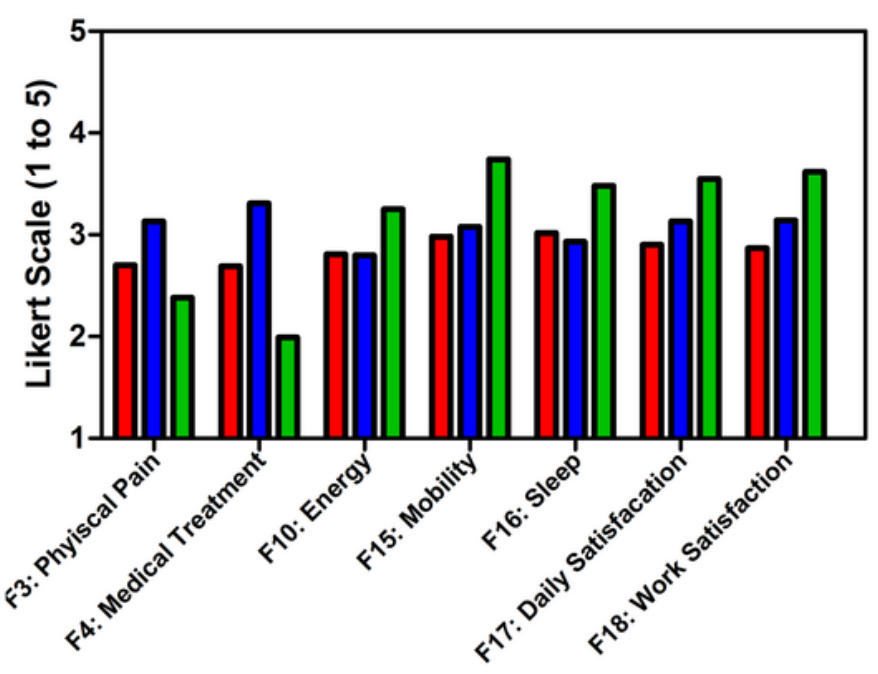

C

Psychological Domain

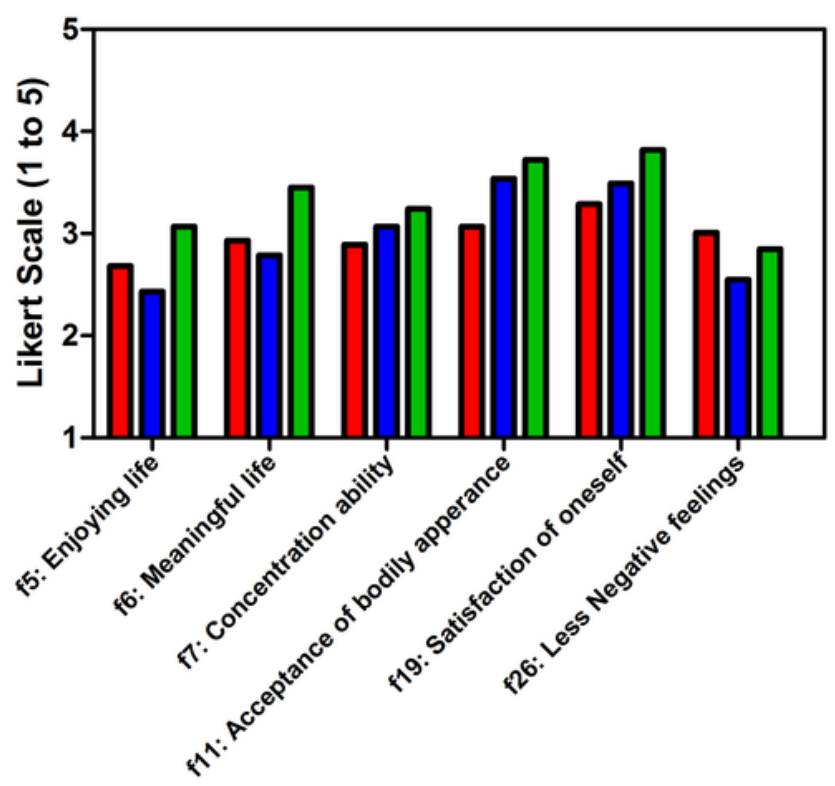

B

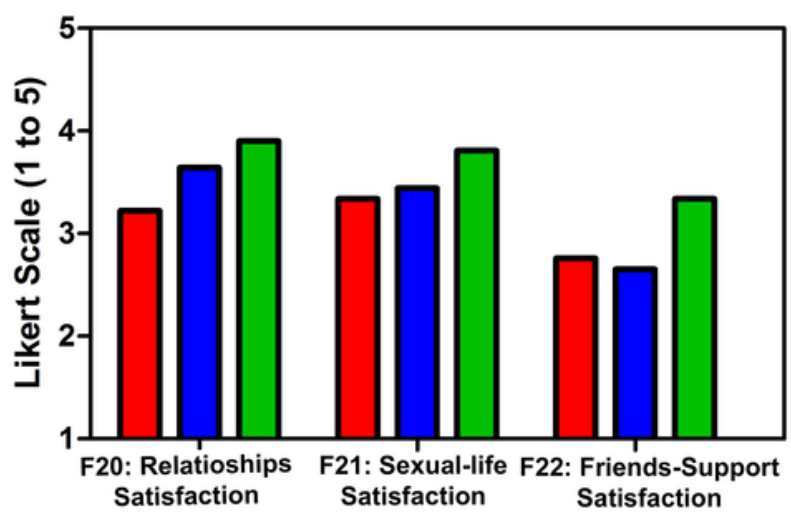

D Environmental Domain

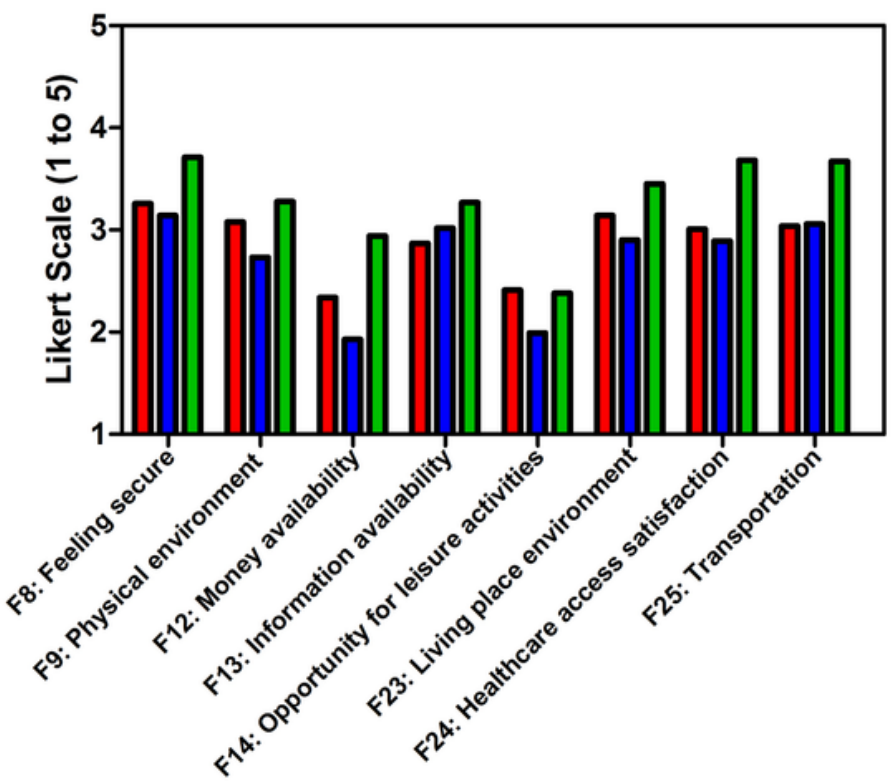


Figure 2

Overall quality-of-life means in Syrians refugees residing outside camps in Jordan and Jordanians.

Mean score for each domain for Syrian refugees, LSES and ASES Jordaninans.

\section{Quality of Life}

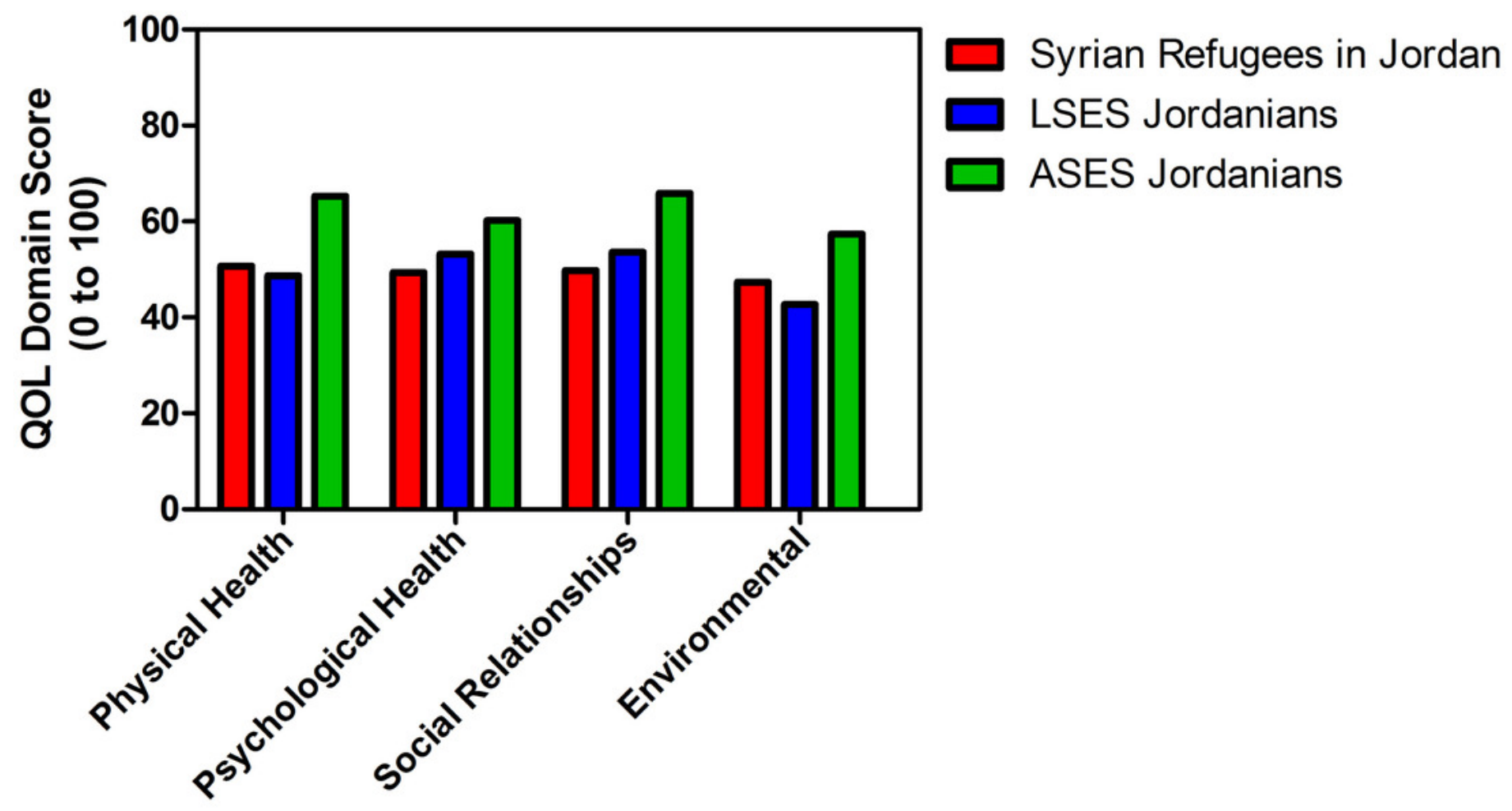

QOL Domain 


\section{Table 1 (on next page)}

General characteristics of the studied groups, Jordan 2017 
1 Table 1:

2 General Characteristics of the studied groups, Jordan 2017.

\begin{tabular}{|c|c|c|c|}
\hline \multirow[b]{2}{*}{ Descriptives } & \multicolumn{3}{|c|}{ Population N (\%) } \\
\hline & $\begin{array}{l}\text { Syrians } \\
655(41.6)\end{array}$ & $\begin{array}{l}\text { LSES Jordanians } \\
208(13.2)\end{array}$ & $\begin{array}{l}\text { ASES Jordanians } \\
712(45.2)\end{array}$ \\
\hline \multicolumn{4}{|l|}{ Gender } \\
\hline Male & $266(40.6)$ & $57(27.4)$ & $116(16.3)$ \\
\hline Female & $389(59.4)$ & $151(72.6)$ & $595(83.7)$ \\
\hline \multicolumn{4}{|l|}{ Age } \\
\hline 18-29 Years & $109(17.0)$ & $34(17.2)$ & $158(23.1)$ \\
\hline 30-39 Years & $202(31.4)$ & $52(26.3)$ & $193(28.2)$ \\
\hline 40-49 Years & $210(32.7)$ & $66(33.3)$ & $157(23.0)$ \\
\hline 50-59 Years & $88(13.7)$ & $28(14.1)$ & $112(16.4)$ \\
\hline 60 Years and above & $34(5.7)$ & $18(9.1)$ & $64(9.4)$ \\
\hline \multicolumn{4}{|l|}{ Education } \\
\hline Illiterate & $46(7.03)$ & $1(0.5)$ & $32(4.5)$ \\
\hline Primary education & $451(69.0)$ & $81(39.0)$ & $115(16.2)$ \\
\hline Secondary education & $98(15.0)$ & 83 (39.9) & $222(31.3)$ \\
\hline College education & $59(9.0)$ & $43(20.7)$ & $341(48.0)$ \\
\hline \multicolumn{4}{|l|}{ Marital status } \\
\hline Single & $22(3.4)$ & $26(12.6)$ & $54(7.6)$ \\
\hline Married & $584(89.4)$ & $140(68.0)$ & $595(83.6)$ \\
\hline Separated & $11(1.7)$ & $25(12.1)$ & $27(3.8)$ \\
\hline Widow & $36(5.5)$ & $15(7.3)$ & $36(5.1)$ \\
\hline \multicolumn{4}{|l|}{ Family size } \\
\hline Small ( $<5$ members $)$ & $186(28.9)$ & $96(47.1)$ & $321(46.0)$ \\
\hline medium (5-7 members) & 321 (49.9) & $81(39.7)$ & $328(47.0)$ \\
\hline Large (>7 members) & $136(21.2)$ & $27(13.2)$ & $49(7.0)$ \\
\hline \multicolumn{4}{|l|}{ Job } \\
\hline Yes & $81(12.6)$ & $34(20.9)$ & $230(33.0)$ \\
\hline No & $560(87.4)$ & $129(79.1)$ & $467(67.0)$ \\
\hline \multicolumn{4}{|l|}{$\begin{array}{l}\text { Monthly income (Per family } \\
\text { JOD) }\end{array}$} \\
\hline Low income $<300$ & $546(89.4)$ & 137 (74.9) & $213(31.1)$ \\
\hline Middle income $300-700$ & $63(10.3)$ & $44(24.0)$ & $378(55.1)$ \\
\hline High income $>700$ & $2(0.3)$ & $2(1.1)$ & 95 (13.9) \\
\hline \multicolumn{4}{|l|}{$\begin{array}{l}\text { Personal description of } \\
\text { financial situation }\end{array}$} \\
\hline Below Average & $505(84.6)$ & $92(60.1)$ & $156(22.4)$ \\
\hline Average and above & $92(15.4)$ & $61(39.9)$ & $540(77.6)$ \\
\hline \multicolumn{4}{|l|}{ Presence of disease } \\
\hline Yes & $393(60.2)$ & $94(45.2)$ & $196(27.5)$ \\
\hline No & $260(39.8)$ & $114(54.8)$ & $516(72.5)$ \\
\hline
\end{tabular}


Table 2 (on next page)

Means of domain's questions for the three populations, Jordan 2017 
1 Table 2:

2 Means of Domain's questions for the three populations, Jordan 2017.

\begin{tabular}{|c|c|c|c|c|}
\hline \multirow[b]{2}{*}{ Domain's questions } & \multicolumn{4}{|c|}{ Population/Means } \\
\hline & $\begin{array}{c}\text { Syrian } \\
\text { population } \\
(\mathrm{N}=655)\end{array}$ & $\begin{array}{c}\text { LSES } \\
\text { Jordanians } \\
(\mathbf{N}=\mathbf{2 0 8})\end{array}$ & $\begin{array}{c}\text { ASES } \\
\text { Jordanians } \\
(\mathbf{N}=712)\end{array}$ & $P$ value \\
\hline \multicolumn{5}{|l|}{ Physical domain } \\
\hline f3: Physical pain & 2.7 & 2.87 & 2.38 & $<.0001$ \\
\hline f4: Need for medical treatment & 2.69 & 2.69 & 1.99 & $<.0001$ \\
\hline f10: Energy & 2.81 & 2.8 & 3.25 & $<.0001$ \\
\hline f15: Mobility & 2.98 & 3.08 & 3.74 & $<.0001$ \\
\hline f16: Sleep & 3.02 & 2.93 & 3.48 & $<.0001$ \\
\hline $\begin{array}{l}\text { f17: Satisfaction of the daily activities } \\
\text { performance }\end{array}$ & 2.9 & 3.13 & 3.55 & $<.0001$ \\
\hline $\begin{array}{l}\text { f18: Satisfaction of the capacity of } \\
\text { work }\end{array}$ & 2.87 & 3.14 & 3.62 & $<.0001$ \\
\hline \multicolumn{5}{|l|}{ Psychological domain } \\
\hline f5: Enjoying life & 2.68 & 2.43 & 3.07 & $<.0001$ \\
\hline f6: Meaningful life & 2.93 & 2.79 & 3.45 & $<.0001$ \\
\hline f7: Concentration ability & 2.89 & 3.07 & 3.24 & $<.0001$ \\
\hline f11: Acceptance of bodily appearance & 3.07 & 3.54 & 3.72 & $<.0001$ \\
\hline f19: Satisfaction of oneself & 3.29 & 3.49 & 3.82 & $<.0001$ \\
\hline f26: Negative feelings & 2.85 & 3.45 & 2.78 & $<.0001$ \\
\hline \multicolumn{5}{|l|}{ Social domain } \\
\hline f20: Relationships satisfaction & 3.22 & 3.64 & 3.9 & $<.0001$ \\
\hline $\begin{array}{l}\text { f21: Sexual life satisfaction } \\
(29,16,158)^{a}\end{array}$ & 3.34 & 3.44 & 3.81 & 0.05 \\
\hline f22: Satisfaction with friends support & 2.76 & 2.65 & 3.34 & $<.0001$ \\
\hline \multicolumn{5}{|l|}{ Environmental domain } \\
\hline f8: Feeling secure & 3.26 & 3.14 & 3.71 & $<.0001$ \\
\hline f9: Physical environment & 3.08 & 2.73 & 3.28 & $<.0001$ \\
\hline f12: Money availability & 2.34 & 1.93 & 2.94 & $<.0001$ \\
\hline f13: Information availability & 2.87 & 3.02 & 3.27 & $<.0001$ \\
\hline f14: Opportunity for leisure activities & 2.41 & 1.99 & 2.38 & $<.0001$ \\
\hline f23: Living place environment & 3.14 & 2.9 & 3.45 & $<.0001$ \\
\hline f24: Healthcare access satisfaction & 3.01 & 2.89 & 3.68 & $<.0001$ \\
\hline f25: Transportation & 3.04 & 3.06 & 3.67 & $<.0001$ \\
\hline
\end{tabular}

*This is on Likert scale were 5 means very satisfied or very good, and 1 means very dissatisfied or very poor

${ }^{\text {a }} \mathrm{N}(\%)$ was $29(4.4 \%)$ for Syrian refugees, 16(7.7\%) for LSES Jordanians and 158(22.2\%) for ASES Jordanians 


\section{Table $\mathbf{3}$ (on next page)}

Stepwise multivariate linear regression for each domains 
1 Table 3:

2 Stepwise multivariate linear regression for each domains.

\begin{tabular}{|c|c|c|}
\hline Variables & $\begin{array}{c}\text { Change in Domain } \\
\text { Scores }\end{array}$ & P-value \\
\hline $\begin{array}{l}\text { Physical Health domain } \\
\text { Intercept } \\
\text { Population } \\
\text { Age } \\
\text { Diseases } \\
\text { Family size } \\
\text { Monthly income } \\
\text { Job } \\
\text { Personal description of financial situation } \\
\text { Marital status }\end{array}$ & $\begin{array}{c}62.75 \\
-3.63 \\
-0.15 \\
-2.5 \\
-0.54 \\
0.01 \\
3.93 \\
3.49 \\
1.22\end{array}$ & $\begin{array}{l}P<0.0001 \\
P<0.0001 \\
P<0.0001 \\
P<0.0001 \\
P<0.05 \\
P<0.0001 \\
P<0.0001 \\
P<0.001 \\
P<0.05\end{array}$ \\
\hline $\begin{array}{l}\text { Psychological Health domain } \\
\text { Intercept } \\
\text { Population } \\
\text { Age } \\
\text { Diseases } \\
\text { Monthly income } \\
\text { Job } \\
\text { Personal description of financial situation } \\
\text { Marital status }\end{array}$ & $\begin{array}{c}52.78 \\
-1.93 \\
-0.11 \\
-0.89 \\
0.01 \\
2.21 \\
6.98 \\
1.1\end{array}$ & $\begin{array}{l}P<0.0001 \\
P<0.001 \\
P<0.001 \\
P<0.05 \\
P<0.001 \\
P<0.05 \\
P<0.0001 \\
P<0.05\end{array}$ \\
\hline $\begin{array}{l}\text { Social relationships domain } \\
\text { Intercept } \\
\text { Population } \\
\text { Diseases } \\
\text { Monthly income } \\
\text { Personal description of financial situation } \\
\text { Marital status }\end{array}$ & $\begin{array}{c}55.38 \\
-5.12 \\
-1.04 \\
0.0 \\
6.80 \\
1.29\end{array}$ & $\begin{array}{l}P<0.0001 \\
P<0.0001 \\
P<0.05 \\
P<0.05 \\
P<0.0001 \\
P<0.05\end{array}$ \\
\hline $\begin{array}{l}\text { Environmental domain } \\
\text { Intercept } \\
\text { Population } \\
\text { Monthly income } \\
\text { Education } \\
\text { Gender } \\
\text { Personal description of financial situation }\end{array}$ & $\begin{array}{c}51.33 \\
-1.05 \\
0.01 \\
-0.14 \\
-2.78 \\
8.54\end{array}$ & $\begin{array}{l}P<0.0001 \\
P<0.05 \\
P<0.0001 \\
P>0.05 \\
P<0.001 \\
P<0.0001\end{array}$ \\
\hline
\end{tabular}




\section{Table 4(on next page)}

Overall means scores for each domain in the three populations (0-100 scale) 
1 Table 4:

2 Overall means scores for each domain in the three populations (0-100 scale).

\begin{tabular}{|l|c|c|c|c|}
\hline \multicolumn{1}{|c|}{ Domain } & $\begin{array}{c}\text { Syrian } \\
\text { population } \\
(\mathbf{N = 6 5 5 )}\end{array}$ & $\begin{array}{c}\text { LSES } \\
\text { Jordanians } \\
(\mathbf{N = 2 0 8 )}\end{array}$ & $\begin{array}{c}\text { ASES } \\
\text { Jordanians } \\
(\mathbf{N = 7 1 2})\end{array}$ & P Value \\
\hline Physical health & 50.68 & 48.68 & 65.28 & $<.0001$ \\
Psychological health & 49.35 & 53.23 & 60.24 & $<.0001$ \\
Social relationships & 49.82 & 53.59 & 65.89 & $<.0001$ \\
Environmental domain & 47.37 & 42.67 & 57.39 & $<.0001$ \\
\hline
\end{tabular}

3 
